\title{
Properties of Magnetically Attractive Experimental Resin Composites
}

\author{
Susumu HIRANO, Hiromi YASUKAWA, Rie NOMOTO, \\ Keisuke MORIYAMA and Tadashi HIRASAWA \\ Department of Dental Engineering, Tsurumi University School of Dental Medicine \\ 2-1-3 Tsurumi, Tsurumi-ku, Yokohama 230, Japan.
}

Received July 9, 1996/Accepted October 26, 1996

\begin{abstract}
SUS444 stainless steel filled chemically cured resin composites that can attract magnet were fabricated. The filler was treated with various concentrations of silane. The experimental composite was easy to handle and showed a good shelf life. The maximal properties obtained are as follows; The attraction force to a magnetic attachment was $1 / 3-1 / 4$ lower than the commercially available magnet-keeper system for dental magnetic attachment. Flexural strength and Knoop hardness of the composite were $76 \mathrm{MPa}$ (7.7kgf/ $\mathrm{mm}^{2}$ ) and $64 \mathrm{KHN}$. These values were lower than the commercially available chemically cured composite used as a reference. Eluted metal from the composite in $1 \%$ lactic acid solution for 7 days showed $0.7 \mathrm{mg} /$ $\mathrm{cm}^{2}$, but in $0.9 \% \mathrm{NaCl}$ solution for 7 days, it could not be detected.
\end{abstract}

Key words : Resin composite, Stainless steel filler, Attraction force to magnet

\section{INTRODUCTION}

The use of magnetic attachment in dental applications is becoming more common in Japan. Magnetic attachment is achieved using a pair of a magnet sealed with stainless steel and a keeper made of ferritic stainless steel as the attractive component ${ }^{1}$. The magnet is normally set in the denture, and the keeper is fixed on the root cap. The keeper is incorporated in the root cap made by casting $\mathrm{Au}$ alloy or $\mathrm{Au}-\mathrm{Pd}-\mathrm{Ag}-\mathrm{Cu}$ alloy.

In the oral environment, the difference in the electrode potentials between the root cap alloy and the keeper causes the keeper to be susceptible to crevice or pitting corrosion if the $\mathrm{Cr}$ content in stainless steel has not been made sufficiently passive. Incorporating the keeper in the root cap during casting is an intricate process. If a resin composite that can attract a magnet should be fabricated, it could be directly molded in a root cap with the keeper as a single unit.

For several years authors studied resin composites that could attract magnets ${ }^{2,3)}$. A new experimental two-paste type resin composite was developed for this purpose. The present study evaluates the properties of this experimental resin composite.

\section{MATERIALS AND METHODS}

\section{Monomer formulation}

The monomer formulation of this composite was bisGMA* (2,2-bis[4-(3-methacryloxy-2-

* Polysciences, Inc., Warrinton, USA 
hydroxypropoxy)phenyl] propane)/TEGDMA** (triethyleneglycol dimethacrylate) $=6 / 4$.

As a catalyst paste, $0.9 \mathrm{wt} \% \mathrm{BPO}$ (benzoyl peroxide) and $0.01 \mathrm{wt} \% \mathrm{MHQ}$ (hydroquinone monomethyl ether) of monomer weight were added. The base paste included $1 \mathrm{wt} \% \mathrm{HEPT}$ (N, N-dihydroxyethyl-p-toluidine).

\section{Filler Treatment}

$18 \% \mathrm{Cr}-2 \% \mathrm{Mo}$ stainless steel (SUS444) powder\# was used. The powder was sieved and passed through a 625 mesh $(<20 \mu \mathrm{m})$ and used as filler as shown in Fig. 1. The filler was immersed in benzene to dissolve the zinc stearate used as a lubricant, then rinsed in acetone. The filler was then treated using $70 \%$ ethyl alcohol solutions with various concentrations of $\gamma$ MPTS ( $\gamma$-methacryloxypropyltrimethoxysilane $)^{4)}$. The concentrations adopted were $1,1.5$ and $3 \mathrm{~g}$ of $\gamma$ MPTS in $100 \mathrm{ml}$ ethyl alcohol solution per $100 \mathrm{~g}$ of filler. The filler was stirred in $60^{\circ} \mathrm{C}$ ethyl alcohol solution containing $\gamma \mathrm{MPTS}$ for $1 \mathrm{~h}$, then oven dried at $120^{\circ} \mathrm{C}$ for $4 \mathrm{~h}$.

Resin composites mixed with $87 \mathrm{wt} \%$ stainless steel filler treated with various concentrations of $\gamma$ MPTS both in catalyst and base paste were fabricated (Table 1).

\section{Setting Time}

A teflon tube $\phi 6 \times 10 \mathrm{~mm}$ was attached with sticky wax to a teflon plate, and a $\mathrm{C}-\mathrm{C}$ thermocouple was placed in the center of the tube. Equal weights of catalyst and base paste were mixed for 30 s at room temperature, then the mixture was used to fill the container at

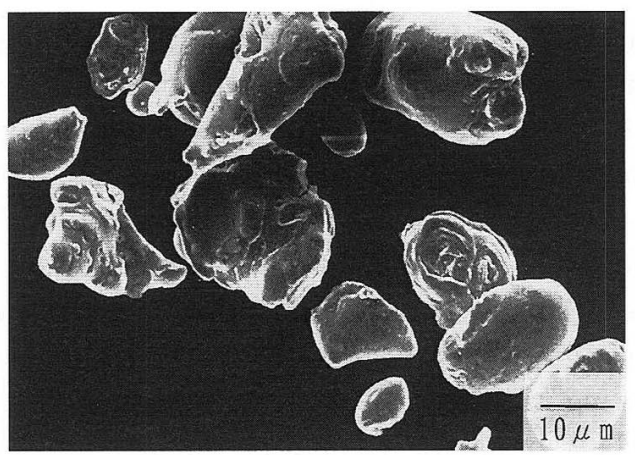

Fig. 1 Stainless steel filler used.

Table 1 Experimental resin composite

\begin{tabular}{lll}
\hline \multicolumn{2}{c}{ Base paste } & \multicolumn{1}{c}{ Catalyst paste } \\
\hline Monomer & bisGMA/TEGDMA(6/4) 13 wt\% & bisGMA/TEGDMA(6/4)13 wt\% \\
& BPO 0.9 wt\%+MHQ 0.01 wt\% & HEPT 1 wt\% \\
Filler* & 18Cr-2Mo stainless steel & $18 \mathrm{Cr}-2$ Mo stainless steel \\
& 87 wt\% (625mesh under) & 87 wt\% (625mesh under) \\
\hline
\end{tabular}

* Filler was treated with various concentration of $\gamma$ MPTS.

** Shin-Nakamura Chemical Co. Ltd., Wakayama, Japan

* Daido Steel Co. Ltd., Tokyo, Japan 
$37^{\circ} \mathrm{C}$. The peak temperature for setting reaction of the composite was measured. The initial setting time was shown as the time from the start of mixing to the peak temperature. Measurements were repeated 5 times.

\section{Flexural strength and Knoop hardness}

Five specimens measuring $2 \times 2 \times 30 \mathrm{~mm}$ were fabricated in a stainless steel mold. A threepoint bending test with a span length of $20 \mathrm{~mm}$ was calculated using an Instron type universal testing machinc with a crosshead speed of $1 \mathrm{~mm} / \mathrm{min}$. The elastic modulus was also calculated from the load measured at the deflection of $0.05 \mathrm{~mm}$.

Specimens were polished with \#1200 emery paper and the Knoop hardness was measured with a load at $0.987 \mathrm{~N}(100 \mathrm{gf})$ and a holding time of $30 \mathrm{~s}$. Three specimens were tested, and five points were measured for each specimen.

\section{Eluted metal}

Disks measuring $\phi 20 \times 1 \mathrm{~mm}$ were fabricated in a stainless steel mold and surfaces were finished with \#1200 emery paper and stored in a desiccator with silica gel for one week to dry completely. Disks were stored in $1 \mathrm{v} / \mathrm{v} \%$ lactic acid solution or $0.9 \% \mathrm{NaCl}$ solution of $50 \mathrm{ml}$ at $37^{\circ} \mathrm{C}$ for 7 days. Solutions were analyzed by ICP and the amount of eluted metal was estimated. Three specimens were tested under each condition.

\section{Attraction force measurement using a mandibular model}

The attraction force of the overlay denture equipped with 2 magnets\# (attraction force 8.88N (900gf) $\times 2$ attached to the keeper) was measured on a mandibular model. This model was chosen because the bilateral mandibular canine teeth were available as abutments, and both abutments were restored with the composite (Fig. 2). The attraction forces of 2 sets of

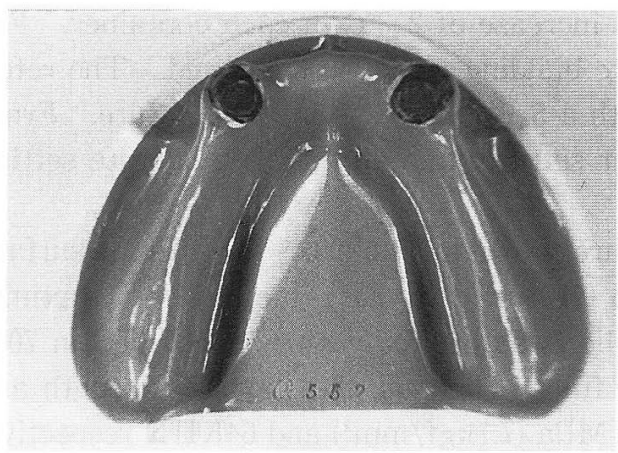

(a)

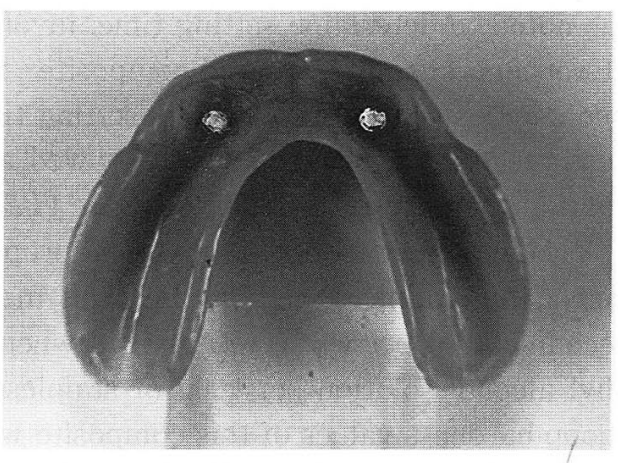

(b)

Fig. 2 (a) The model of the mandibular both side of canine tooth as the abutment (b) The denture corresponded to the model equipped 2 magnets

\# Hicorex Super4515, J. Morita Corp., Tokyo, Japan. 


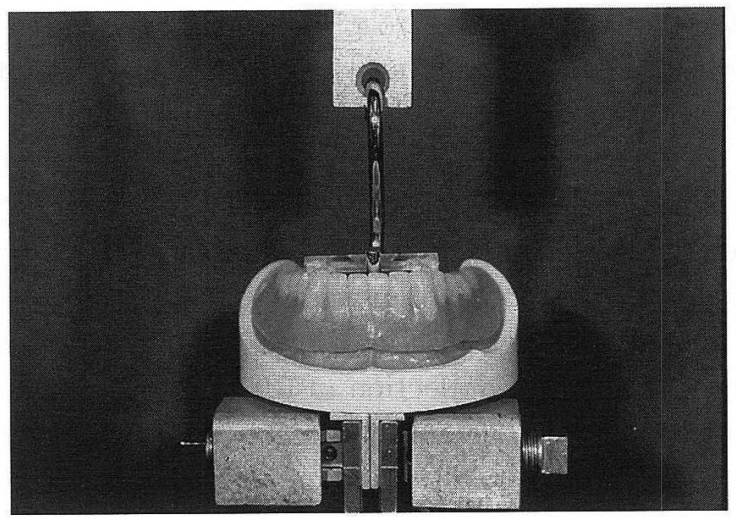

Fig. 3 The attraction force measurement of the denture on the model.

partial dentures were measured using the Instron type universal testing machine at a crosshead speed of $1 \mathrm{~mm} / \mathrm{min}$ (Fig. 3). Measurements were obtained 7 times in each overlay denture.

\section{RESULTS AND DISCUSSION}

The experimental two-paste type composite has a good shelf life and is easily handled during restoration. These pastes did not set within 6 months at room temperature, although in a previous report ${ }^{5}$ the catalyst paste set within two weeks after fabrication. This may be due to a reaction between solute ferric ion from the filler and the impurities of bisGMA used. The bisGMA used in the present study was higher purity than previous report ${ }^{6}$.

The initial setting time of the composite was 3 min 20 s and the peak temperature which was noted to determine setting time, involved an increase of $2-3^{\circ} \mathrm{C}$ in each container. For reference, a chemically cured composite ${ }^{\circledR}$ for core building was also measured. The reference composite showed $2 \mathrm{~min} 18 \mathrm{~s}$ setting time with a $5-9^{\circ} \mathrm{C}$ increase in temperature. From these results, the test composite showed a longer setting time and more moderate setting reaction than the reference composite (Table 2).

The measurements of mechanical properties are shown in Table 3. The specific surface area of the stainless steel powder was measured $0.108 \mathrm{~m}^{2} / \mathrm{g}$ by BET method ${ }^{@}$. Maximal mechanical properties were obtained when the filler was treated with $1.5 \mathrm{~g}$ MPTS in $70 \%$ ethyl alcohol solution per $100 \mathrm{~g}$ of stainless steel filler. That is, the flexural strength and Knoop hardness values of this composite were $76 \mathrm{MPa}\left(7.7 \mathrm{kgf} / \mathrm{mm}^{2}\right)$ and $64 \mathrm{KHN}$ respectively. But those were about $20 \%$ lower than the reference composite. The volume fraction of filler in the experimental composite was under $50 \mathrm{vol} \%$, while that of the reference composite was over $60 \mathrm{vol} \%$. The elastic modulus of the experimental composite was equal to that of the reference composite. This was influenced by the large difference of the elastic modulus

\footnotetext{
(a) Coalite, GC Corp., Tokyo, Japan

@@ measured by Flow Sorb II, Shimadzu, Kyoto, Japan
} 
between the stainless steel filler and silica filler.

The properties of the composite with powder reinforced cannot be predicted because factors affecting the properties were many, such as the degree of adhesion bond between filler and matrix, shape of filler, filler content, and types of dispersion (filler was agglomerated, or in contact with each other $)^{7-9}$. In the composite with high filler content the interparticle distance between the filler shortened, therefore the effect of reinforcing was enhanced. The low flexural strength and the hardness of the experimental composite mainly depend upon the weakness of the filler/matrix interface judged on the flexural strength, and also upon lower filler content and larger filler size than the reference composite, although the filler was treated with silane. In general, the low flexural strength of restorative materials causes breakdown at the margins, so an improvement in mechanical properties of the composite is nessesary for clinical application. Especially, the filler size of this composite is larger than that of commercially available composites, and a smaller filler must be used for that reason.

The results of the eluted metal from the composite are shown in Table 4. The elution

Table 2 Setting time of composites

\begin{tabular}{|c|c|c|}
\hline Composite & Setting Time & Temp increased \\
\hline Exp composite & $3 \min 20 s(9 s)$ & $2-3^{\circ} \mathrm{C}$ \\
\hline Chemical cured composite & $218(9)$ & $5-9$ \\
\hline
\end{tabular}

$($ ):SD

Table 3 Effect of silane treatment to filler on mechanical properties of composite

\begin{tabular}{cccc}
\hline $\begin{array}{c}\text { Silane concenteration } \\
(\mathrm{g})^{*}\end{array}$ & $\begin{array}{c}\text { Flexural strength } \\
(\mathrm{MPa})\end{array}$ & $\begin{array}{c}\text { Elastic modulous } \\
(\mathrm{GPa})\end{array}$ & KHN \\
\hline 1.0 & $58.2(3.9)$ & $9.36(0.81)$ & \\
1.5 & $76.0(6.9)$ & $13.67(1.04)$ & $64(12)$ \\
3.0 & $63.1(3.0)$ & $9.22(0.74)$ & \\
Chemical cured composite & $105.6(2.0)$ & $13.06(0.97)$ & $88(16)$ \\
\hline
\end{tabular}

${ }^{*} \gamma$ MPTS was added in $100 \mathrm{ml}$ of $70 \%$ ethanol solution to treat $100 \mathrm{~g}$ of stainless steel. ( ) : SD

Table 4 Eluted metal after immersion in $1 \%$ lactic acid and $0.9 \%$ sodium cloride solutions

\begin{tabular}{lcc}
\hline & $1 \mathrm{v} / \mathrm{v} \%$ lactic acid solution & $0.9 \%$ sodium cloride solution \\
\hline Exp composite & $0.70(0.03) \mathrm{mg} / \mathrm{cm}^{2}$ & Not detectable \\
\hline
\end{tabular}

Immersion period : 7 days, ( ):SD

Table 5 Attraction force of denture to the magnet for magnetic attachment

\begin{tabular}{lcl}
\hline \multicolumn{1}{c}{ Composite } & Attraction force(N) & \multicolumn{1}{c}{ References } \\
\hline Exp composite & $4.39(0.24)$ & Magnet* $^{*} 8.88 \mathrm{~N} \times 2=17.76 \mathrm{~N}$ \\
& $4.26(0.53)$ & \\
Exp composite $\#$ & $3.33(0.56)$ & Magnet** $^{*} 5.92 \mathrm{~N} \times 2=11.84 \mathrm{~N}$ \\
Keeper/Magnet & $10.69(0.45)$ & Magnet** $^{*} 5.92 \mathrm{~N} \times 2=11.84 \mathrm{~N}$ \\
\hline
\end{tabular}

* Hicorex Super(4515), ** Magfit 600,

\# former reported data, see ref. (3). 
test was according to the Japanese approval specification for dental casting $\mathrm{Ni}-\mathrm{Cr}$ alloy. In $1 \%$ lactic acid solution, $90 \%$ of metal eluted from the composite was $\mathrm{Fe}$, while $\mathrm{Cr}$ comprised about $10 \%$. The total amount of eluted metal was $0.7 \mathrm{mg} / \mathrm{cm}^{2}$. The value is below the value of Japanese approval specifications for dental casting $\mathrm{Ni}-\mathrm{Cr}$ alloys for $\mathrm{Ni}$ (below $1 \mathrm{mg} / \mathrm{cm}^{2}$ ).

Using $0.9 \% \mathrm{NaCl}$ solution, there was no significant difference between the solution in which the specimen was immersed and the blank solution. Therefore the composite should be acceptable for clinical applications.

The attraction force measured using the mandibular model was also similar to those reported previously ${ }^{3)}$ (Table 5). The attraction force decreased by $25 \%$ of the magnetkeeper system when the composite was used. When another 2 magnets $\$$ (attractive force 5. $9 \mathrm{~N}(600 \mathrm{gf} \times 2))$ were used in the mandibular model and keepers were attached, the attraction force obtained was $10.2 \mathrm{~N}$ (1,033gf), and when composites containing $17 \mathrm{Cr}-2 \mathrm{Mo}$ stainless steel filler were used instead of keepers, the attraction force was $3.3 \mathrm{~N}(337 \mathrm{gf})^{3}$. The attractive force decreased 1/3-1/4 compared to that with the keeper attached. Since electro-magnetic properties cannot be predicted from the simple "law of mixture"10), the data obtained is considered reasonable. Therefore, in clinical situations, the composite should be applied the over denture for children or some cases to molars, since the composite has less influence on MRI (Magnetic Resonance Image) than the keeper ${ }^{11}$.

\section{CONCLUSION}

This new experimental composite has a good shelf life and can be easily handled during restoration.

The flexural strength and the Knoop hardness value of this composite were $76 \mathrm{MPa}$ $\left(7.7 \mathrm{kgf} / \mathrm{mm}^{2}\right)$ and $64 \mathrm{KHN}$ respectively, when the filler was treated with $1.5 \mathrm{~g} \gamma \mathrm{MPTS}$ in $70 \%$ ethyl alcohol solution per $100 \mathrm{~g}$ of stainless steel filler. However, mechanical properties of the composite require improvement for clinical application.

After immersion in $1 \%$ lactic acid solution at $37^{\circ} \mathrm{C}$ for 7 days, the total amount of metal eluted from the composite was $0.7 \mathrm{mg} / \mathrm{cm}^{2}$. This value is below the Japanese approval specifications for dental casting $\mathrm{Ni}-\mathrm{Cr}$ alloys for $\mathrm{Ni}\left(1 \mathrm{mg} / \mathrm{cm}^{2}\right)$.

The attraction force measurement using a mandibular model showed a $25 \%$ decrease in attraction force of the magnet/composite system compared to the magnet/keeper system.

\section{REFERENCES}

1) Tanaka, Y.: Dental magnetic attachment, Ishiyaku Publishers Inc. 1992. (in Japanese)

2) Hirano, S. and Hirasawa, T. : Soft magnetic stainless filler filled composites, J J Mag Dent 3 (1): 9-13, 1994. (in Japanese)

3) Hirano, S., Moriyama, K. and Hirasawa, T. : Composite resins attractive to magnet, Dental Materials Forum 8 (8): 6-11, 1995. (in Japanese)

4) Miyazaki, K., Inoue, T., Kikuchi, H., Hirose, H., Nishiyama, N., Anzai, M. and Nishiyama, M. : Density, specific surface area and particle distribution of surface-treated silica, $J J$ Dent Mater 12 (2): 250-264, 1993. (in Japanese)

$\$$ Magfit 600, GC Corp., Tokyo, Japan 
5) Hirano, S. and Hirasawa, T. : Soft magnetic stainless steel powder filled composites, $J J$ Dent Mater 12 (Special issue 22) : 142-143, 1993. (in Japanese)

6) Harashima, I., Imai, K., Nakamura, M. and Hirasawa, T. : Cytotoxity of dental monomers, $J$ J Dent Mater 13 (6) : 563-567, 1994. (in Japanese)

7) Nielsen, L. E. (translated by Onogi, S.) : Mechanical properties of polymers and composites, kagakudoujin, 1976, pp266. (in Japanese)

8) Bayne, S. C., Tayer D. F. and Heyman, H. O.: Protection hypothesis for composite wear, Dent Mater 8 (5) : 305-309, 1992.

9) Taya, M.: Foundation and application of micromechnics models for prediction of composite properties (1), Materia Japan 33 (3) : 276-288, 1994. (in Japanese)

10) Taya, M.: Foundation and application of micromechnics models for prediction of composite properties (2), Materia Japan 33 (4) : 409-416, 1994. (in Japanese)

11) Morito, M. and Hosoi, T. : Effects of dental magnetic keeper materials on MRI, J Jpn Prosthodont Soc. 40 (3) : 426-432, 1996. (in Japanese) 


\section{本号掲載論文の和文抄録}

\section{歯科用チタン:アメリカにおける研究の推移}

中島裕, 岡部 徹

Department of Biomaterials Science, Baylor College of Dentistry

近年, チタンは材料学研究者や臨床医に大きく注目を 浴びてきている.アメリカでのチタンの生体材料として の歴史は, 1940 年にチタンインプラントの動物実験が行 われた時から始まる. その後, 1959 年, 口腔内インプラ ントを作製するにあたりチタン鋳造の必要性をアメリカ の Bedger と Ploger がはじめて唱えた. 1977 年には最 初のチタン鋳造による歯科補綴物が作製する試みがなさ れたと報告されている. 過去 10 年間, IADR および
AADR においてチタンに関連する発表数は毎年増加し 続けている. 大多数の研究発表は, アメリカからの研究 であるが，そのうち半数以上は歯科用インプラントに関 連したものである.チタン鋳造や補綴物としての応用に 関するアメリカからの報告は, 近年増加しているものの, 今のところ数が限られている.このレポートは, アメリ カにおける歯科用チタンの発展と研究の動向を報告す る.

\section{磁石と吸引する試作コンポジットレジンの性質 平野 進, 安川宏美, 野本理恵, 森山圭介, 平澤 忠 鶴見大学歯学部歯科理工学教室}

SUS 444 ステンレス鋼フィラーを含み, 磁石と吸着す る化学重合型コンポジットレジンを作製した. フィラー には種々の濃度のシラン処理を施した.このコンポジッ トレジンは操作性がよく, 保存安定性に優れていた.もっ とも良い性質を示したコンポジットレジンは以下のよう であった. 市販磁性アタッチメント用の磁石に対する吸 引力は磁石附属のキーパシステムのそれの 1/3-1/4で
あった. 曲げ強さとヌープ硬さは各々 $76 \mathrm{MPa}$ (7.7 kgf/ $\left.\mathrm{mm}^{2}\right)$ ならびに $64 \mathrm{KHN}$ で, 市販の化学重合型コア用コ ンポジットレジンよりも低い值であった.コンポジット レジンからの溶出金属量は $1 \%$ 乳酸溶液 7 日間浸漬の結 果 $0.7 \mathrm{mg} / \mathrm{cm}^{2}$ で, $0.9 \% \mathrm{NaCl}$ 溶液 7 日間浸漬では検出 できなかった。

\section{フィラー形状および粒径が武作光重合型コンポジットレジンの 機械的性質に及ぼす影響}

宮坂 平

日本歯科大学歯学部歯科理工学教室

平均粒径 $1.7 \sim 21.5 \mu \mathrm{m}$ の無定形フィラー 4 種類, 平 均粒径 0.46 ～ $31.2 \mu \mathrm{m}$ の球形フィラー 5 種類および平 均 $0.04 \mu \mathrm{m}$ のミクロフィラーのうちから, それぞれ 2 種 類づつを組み合わせて混合した二成分系のハイブリッド
型フィラーを用い光重合型コンポジットレジンを試作 し, 圧縮強さおよび間接引張強さを測定した.この結果, 無定形フィラーと球形フィラーを混合すると, 組み合わ せるフィラーの粒径が小さいほど強度は大きくなる傾向 